\title{
KREASI KREATIF MENGGUNAKAN BAHAN KERTAS KADO DENGAN TEKNIK ANYAMAN PADA PEMBELAJARAN SENI BUDAYA DAN KETERAMPILAN DI SDN 26 PARAK BURUK DAN SDN 53 KAMPUNG JAMBAK KEC. KOTO TANGAH
}

\author{
Eliya Pebriyeni $^{1 *}$, Lisa Widiarti ${ }^{2 *}$ \\ Program Studi Pendidikan Seni Rupa Jurusan Seni Rupa Fakultas Bahasa dan Seni \\ Universitas Negeri Padang \\ Jl. Prof. Dr. Hamta, Air Tawar Padang, Kel. Air Tawar Barat, Kec. Padang Utara, Kota Padang, Kode Pos 25171 \\ Sumatera Barat. Indonesia \\ Email:elyafebriyeni@gmail.com
}

\begin{abstract}
Abstrak
Guru yang mengajarkan materi pembelajaran untuk Seni Budaya dan Keterampilan, bahan yang digunakan biasanya masih berorientasi pada bahan buatan pabrik yang diperdagangkan. Namun, ternyata bahan yang digunakan sebagai bahan praktis dapat menggunakan bahan dari berbagai jenis kertas yang digunakan sebagai karya. Bahan kertas yang digunakan sebagai pekerjaan dapat diproses menggunakan teknik anyaman. Bahan kertas yang dapat digunakan sebagai karya termasuk: kertas plastik, kertas koran, kertas majalah, kertas HVS, kertas manila, kertas kado, dan sebagainya. Penggunaan kertas kado dalam membuat karya yang nantinya akan diolah menggunakan teknik anyaman sebagai bahan pembelajaran untuk Seni Budaya dan Keterampilan memberikan banyak manfaat, Selain tujuan pembelajaran dapat dicapai, juga dapat mendidik siswa untuk dapat menggunakan objek yang ada di lingkungan. Prioritas masalah ditetapkan oleh Tim pelaksana bersama dengan Kepala SDN 26 Parak Buruk dan SDN 53 Kampung Jambak Padang. Masalah yang harus dipecahkan dilihat dari dua aspek kegiatan pembelajaran, yaitu: (1) manajemen materi praktik pembelajaran, (2) penguasaan dan penerapan bahan pembelajaran untuk Seni Budaya dan Keterampilan. Pembenaran utama dalam menentukan masalah yang harus dipecahkan adalah untuk meningkatkan kualitas pembelajaran dalam Seni Budaya dan Keterampilan di sekolah dasar. Prioritas masalah ditetapkan oleh Tim pelaksana bersama dengan Kepala SDN 26 Parak Buruk dan SDN 53 Kampung Jambak Padang. Masalah yang harus dipecahkan dilihat dari dua aspek kegiatan pembelajaran, yaitu: (1) manajemen materi praktik belajar, (2) penguasaan dan penerapan materi pembelajaran Seni Budaya dan Keterampilan. Pembenaran utama dalam menentukan masalah yang harus dipecahkan adalah untuk meningkatkan kualitas pembelajaran dalam Seni Budaya dan Keterampilan di sekolah dasar. Kegiatan pemecahan masalah dilakukan dengan pendekatan: Desain, konseling, pelatihan / lokakarya, dan implementasi. Sampai laporan kemajuan ini disiapkan, kegiatan target yang telah dicapai adalah: (1) Ada peningkatan pemahaman guru SDN Mitra di: Memahami konsep, konsep, dan proses pembuatan karya dengan menggunakan bahan kertas pembungkus dengan teknik tenunan dari $40 \%$ hingga $78 \%$. (2) Produk yang dihasilkan berupa: (a) media pembelajaran dan model kerja, (b) identifikasi bahan praktikum dari kertas kado yang ada di lingkungan siswa, (c) kerajinan yang terbuat dari bahan sampah, yaitu kertas kado. Tahap selanjutnya dari rencana adalah melakukan kegiatan: Menulis artikel dan mengirim artikel ke jurnal ilmiah.
\end{abstract}

Kata Kunci: praktikum, kertas kado, anyaman

\begin{abstract}
Teachers who teach learning materials for Cultural Arts and Skills, the materials used are usually still oriented to the factory-made materials that are traded. However, it turns out that the materials used as practical materials can use materials from various types of paper that are used as works. The paper material used as the work can be processed using woven techniques. Paper materials that can be used as works include: plastic paper, newsprint, magazine paper, HVS paper, manila paper, wrapping paper and so on. The use of gift paper in making works that will later be processed using woven techniques as learning material for Cultural Arts and Skills provides multiple benefits, besides learning objectives can be achieved, it can also educate students to be able to use objects that are in the environment. Priority issues were set by the Implementation Team together with the Head of SDN 26 Parak Buruk and SDN 53 Kampung Jambak Padang. Problems to be solved are seen from two aspects of learning activities, namely: (1) management of learning practice materials, (2) mastery and application of learning materials for Cultural Arts and Skills. The main justification in determining the problems to be solved is
\end{abstract}




\section{Gorga Jurnal Seni Rupa \\ Volume 07 Nomor 02 \\ p-ISSN: 2301-5942 | e-ISSN: 2580-2380}

to improve the quality of learning in Cultural Arts and Skills in elementary schools. Problem solving activities are carried out with an approach: Design, counseling, training / workshop, and implementation. Until this progress report is prepared, the target activities that have been achieved are: (1) There is an increase in understanding of SDN Mitra teachers in: Understanding the concepts, concepts, and processes of making work by using wrapping paper materials with woven techniques from $40 \%$ to $78 \%$.(2) Produced products in the form of: (a) learning media and work models, (b) identification of practicum material from wrapping paper that is in the student's environment, (c) handicrafts made from waste material, namely gift paper. The next stage of the plan is to carry out activities: Writing articles and sending articles to scientific journals.

Keywords: practicum, wrapping paper, webbing

\section{PENDAHULUAN}

Kunci sukses yang menentukan keberhasilan implementasi kurikulum 2013 adalah kompetensi guru, karena guru merupakan faktor penting yang besar pengaruhnya, bahkan sangat menentukan berhasil tidaknya siswa dalam belajar. Ketidaksiapan guru tidak hanya terkait dengan urusan kompetensi mengajar saja, tetapi juga berkaitan dengan masalah kreatifitasnya. Seorang guru yang akan mendidik dalam bidang pendidikan seni rupa membutuhkan dasar-dasar pengetahuan dan keterampilan yang sesuai dengan tuntutan bidang tersebut. Penguasaan dasardasar pengetahuan dan keterampilan tersebut meliputi pengetahuan tentang pendekatan dan metode pembelajarannya. Pendekatan dan metode dalam pembelajaran seni rupa merupakan dasar pengetahuan yang mesti dikuasai seorang guru ketika akan mempersiapkan diri dalam perancangan pembelajaran.

Sesuai dengan Peraturan Menteri Pendidikan Nasional Nomor 23 tahun 2006. Materi pembelajaran Seni Budaya dan Keterampilan di Sekolah Dasar adalah: (1) seni rupa, mencakup pengetahuan, keterampilan, dan nilai dalam menghasilkan karya seni. (2) seni musik, mencakup kemampuan untuk menguasai olah vokal, memainkan alat musik, apresiasi karya musik. (3) seni tari, keterampilan gerak berdasarkan olah tubuh dengan dan tanpa rangsangan bunyi, apresiasi terhadap tari. (4) seni drama, mencakup keterampilan pementasan dengan memadukan seni musik, seni tari dan peran. (5) keterampilan, mencakup segala aspek kecakapan hidup (life skills).

Semua cakupan materi pembelajaran tersebut tentunya harus dipelajari tetapi pada kenyataan tidak semua dapat dipelajari karena salah satu faktornya adalah kompetensi guru yang hanya berkompeten dalam satu bidang saja. Pendidikan Seni Budaya dan Keterampilan merupakan mata pelajaran produktif, sehingga sangat penting adanya upaya perubahan dan peningkatan dalam proses pembelajaran mencipta sebuah karya. Hal ini pada akhirnya akan memberikan hasil dan kreativitas yang baik sehingga pembelajaran semakin meningkat.

Seni Budaya dan Keterampilan sebagai mata pelajaran di sekolah seharusnya dapat dirasakan sangat penting keberadaannya bagi siswa, karena mata pelajaran Seni Budaya dan Keterampilan memiliki sifat multilingual, multidimensional, dan multikultural.Multilingual bertujuan mengembangkan kemampuan mengekspresikan diri dengan berbagai cara. Multidimensional berarti bahwa mengembangkan kompetensi kemampuan dasar siswa yang mencakup persepsi, pengetahuan, pemahaman, analisis, evaluasi, apresiasi, dan produktivitas dalam menyeimbangkan fungsi otak kanan dan kiri, dengan memadukan unsur logika, etika, dan estetika. Adapun multikultural bertujuan menumbuhkembangkan kesadaran dan kemampuan berapresiasi.

Berdasarkan uraian di atas dapat ditarik kesimpulan bahwa dalam pembelajaran Seni Budaya dan Keterampilan sangat penting selain itu kompetensi guru juga sangat dituntut untuk meningkatkan kreativitas murid. Bahkan latar belakang pendidikan guru juga sangat menentukan proses belajar mengajar yang efektif. Salah satu upaya untuk meningkatkan kompetensi guru adalah guru harus bisa memilih bahan yang cocok yang ada di lingkungan sekitar untuk dijadikan bahan dalam pembuatan prakarya. Guru juga harus mampu meningkatkan pemahamannya tentang pembelajaran seni budaya dan keterampilan.

SDN 26 Parak Buruk dan SDN 53 Kampung Jambak Padang berlokasi di kelurahan Batipuh Panjang, Kecamatan Koto Tangah. Kedua sekolah ini berjarak sekitar 10 kilo meter dari kampus Universitas Negeri Padang. SDN 26 Parak Buruk merupakan salah satu SD Standar Nasional yang ada di Kota Padang. Memiliki murid sebanyak 110 orang (63 pria dan 47 wanita). SDN 26 Parak Buruk memiliki 6 kelas dari kelas 1 sampai kelas 6, kelas I memiliki jumlah murid 
18 orang, kelas II 15 orang, kelas III 20 orang, kelas IV 16 orang, kelas V 22 orang, kelas VI 19 orang. Kegiatan pembelajaran SDN 26 Parak Buruk dilaksanakan oleh 6 orang guru kelas, 1 orang laki-laki untuk guru penjaskes (S1), 1 orang laki-laki untuk guru agama (DII). Dari 6 orang guru kelas, 5 orang guru yang sudah PNS dan 1 orang guru honorer. Serta dari 6 orang guru kelas tersebut, 5 orang tamatan S1 dan 1 orang yang tamatan DII. Sedangkan SDN 53 Kampung Jambak memiliki murid sebanyak 141 orang (87 pria dan 54 wanita). SDN 53 Kampung Jambak juga memiliki 6 kelas dari kelas 1 sampai kelas 6, kelas I memiliki jumlah murid 26 orang, kelas II 28 orang, kelas III 23 orang, kelas IV 20 orang, kelas V 23 orang, kelas VI 21 orang. Kegiatan pembelajaran SDN 53 Kampung Jambak dilaksanakan oleh 6 orang guru kelas, 2 orang guru agama. Dari 6 orang guru kelas, 3 orang guru yang sudah PNS dan 3 orang guru yang belum PNS (guru honorer).

Kurangnya kemampuan guru SDN 26 Parak Buruk dan SDN 53 Kampung Jambak dalam menguasai materi, kemungkinan juga disebabkan karena bervariasinya tingkat pendidikan yang dimiliki, ada tamatan dari SPG dan ada yang sudah sarjana, selain itu juga terlihat dari status kepegawaian (PNS dan honorer), secara otomatis kemampuan yang dimiliki guru juga bervariasi. Rendahnya tingkat pendidikan guru, dan variasi kemampuan guru menyebabkan rendahnya kemampuan mereka untuk menguasai materi pembelajaran sesuai dengan Standar Kompetensi (SK) dan Kompetensi Dasar (KD) yang akan dicapai dalam pembelajaran, khususnya pembelajaran Seni Budaya dan Keterampilan/Prakarya.

Aspek permasalahan lain yang ditemukan adalah dalam pembuatan karya pada pelajaran seni budaya dan keterampilan. Bila guru melaksanakan kegiatan pembelajaran seni budaya dan keterampilan, maka karya yang biasa diberikan bersifat monoton, karena dari tahun ke tahun bahan praktikum yang dipergunakan guru tidak berubah dan tidak bervariasi. Dan bahkan materi pembelajaran seni budaya dan keterampilan tidak diajarkan, hanya diberikan tugas karya pada saat pelaksanaan kelas meting.

Pengabdian kepada masyarakat ini difokuskan pada dua aspek permasalahan utama pada pelaksanaan pembelajaran Seni Budaya dan Keterampilan yaitu: (1) Manajemen bahan praktikum pembelajaran seni budaya dan keterampilan, dan (2) penguasaan dan penerapan materi pembelajaran seni budaya dan keterampilan. Rendahnya kompetensi guru dalam menguasai materi pembelajaran, kurangnya pemahaman dan pengetahuan guru terhadap pemanfaatan bahan yang ada dilingkungan sekitar, siswa tidak mengerjakan sendiri tugas yang diberikan oleh guru, pada umumnya banyak siswa yang membeli tugas bukan mengerjakan sendiri. Aspek permasalahan yang lain adalah dalam penggunaan bahan praktikum Seni Budaya dan Keterampilan. Bila guru melaksanakan kegiatan pembelajaran Seni Budaya dan Keterampilan, maka bahan praktikum yang dipergunakan guru masih berorientasi kepada barang pabrik yang diperjual-belikan di pasar. Artinya, bahan untuk pembuatan karya harus dibeli, dan sering kali harga relatif mahal untuk kegiatan pembelajaran di SD. Padahal berbagai bahan yang ada di sekeliling sekolah atau rumah murid dapat dijadikan sebagai bahan praktikum. Bahan-bahan tersebut bisa berupa barang-barang bekas, bagian dari tumbuhtumbuhan, tanah liat, biji-bijian atau batu-batuan, dari bahan-bahan kertas yang harganya tidak terlalu mahal. Penggunaan bahan kertas yang dijadikan sebagai bahan pembelajaran Seni Budaya dan Keterampilan memberikan keuntungan ganda.

Untuk mengatasi masalah, bahan pratikum yang akan dilakukan dengan menggunakan bahan kertas kado, sedangkan untuk mengatasi masalah penguasaan materi pembelajaran, diberikan materi pembelajaran tentang teknik anyaman yang tidak terlalu menuntut kemampuan guru dalam menggambar yaitu dengan membuat benda-benda yang memiliki nilai pakai yang dalam pelaksanaannya dapat dilakukan belajar sambil bermain.Pembuatan benda siap pakai dengan menggunakan bahan kertas kado ini merupakan salah satu teknik pengekspresian diri dalam materi pembelajaran Seni Budaya dan Keterampilan yang dilakukan dengan menggunakan teknik anyaman. Dari segi biaya yang dikeluarkan, jelas pemanfaatan dari bahan kertas kado ini memiliki harga murah, bahkan tanpa biaya, kalau seandainya kertas kado diperoleh dari kertas-kertas kado bekas. Bahan ini mudah dicari di sekitar lingkungan tempat tinggal. Sekaligus memiliki efek pengiring, yaitu mendidik murid untuk bisa memanfaatkan bahan-bahan yang mudah diperoleh dari lingkungan sekitar.

Berdasarkan gambaran analisis situasi, ditemukan berbagai permasalahan yang di hadapi guru SDN 26 Parak Buruk dan SDN 53 Kampung Jambak (SDN Mitra) dalam melaksanakan kegiatan pembelajaran. Dari segi kegiatan pembelajaran Mata Pelajaran Seni Budaya dan keterampilan, khususnya materi pembelajaran seni rupa dan keterampilan ditemukan masalah yaitu: rendahnya kompetensi guru dalam 


\section{Gorga Jurnal Seni Rupa \\ Volume 07 Nomor 02 \\ p-ISSN: 2301-5942 | e-ISSN: 2580-2380}

menguasai materi pembelajaran, kurangnya pemahaman dan pengetahuan guru terhadap pemanfaatan bahan-bahan yang ada disekitar murid, siswa tidak mengerjakan sendiri tugas yang diberikan oleh guru, pada umumnya banyak siswa yang membeli tugas bukan mengerjakan sendiri.

Masalah prioritas ditetapkan secara bersama-sama antara Tim Pelaksana dengan Kepala SDN 26 Parak Buruk dan SDN 53 Kampung Jambak. Masalah prioritas yang akan diselesaikan dilihat dari dua aspek kegiatan pembelajaran materi seni rupa dan keterampilan yang saling berkorelasi, yaitu masalah pada aspek: (1) Manajemen bahan praktikum pembelajaran Seni Budaya dan Keterampilan, Guru SDN 26 Parak Buruk dan SDN 53 Kampung Jambak Kec. Koto Tangah Padang belum dapat: mengidentifikasi dan mengelola bahan kertas apa saja yang bisa dijadikan karya siap pakai yang ada di sekitar murid sebagai bahan praktikum pembelajaran Seni Budaya dan Keterampilan, dan belum dapat memilih dan mempersiapkan kertas kado sebagai bahan yang dijadikan karya dalam pembuatan karya siap pakai dengan menggunakan teknik anyaman pada pembelajaran Seni Budaya dan Keterampilan. (2) Penguasaan dan penerapan materi pembelajaran Seni Budaya dan Keterampilan, Guru SDN 26 Parak Buruk dan SDN 53 Kampung Jambak Kec. Koto Tangah Padang belum dapat: memahami pengertian, konsep, dan proses pembuatan karya siap pakai dengan menggunakan teknik anyaman, belum dapat membuat karya siap pakai dengan menggunakan teknik anyaman dari bahan kertas kado yang ada di sekitar murid.

\section{KAJIAN TEORI}

Kajian teori merupakan suatu perangkat untuk melakukan penelitian dalam menyelidiki masalah yang diteliti, menyusun bahan yang diperoleh, analisis sumber dan analisis hasil temuan di lapangan. Sehubungan dengan hal ini, Lexy J. Moleong dalam Metodologi Penelitian Kualitatif, menjelaskan bahwa seorang peneliti yang mengadakan penelitian kualitatif biasanya berorientasi pada teori yang sudah ada. Pada penelitian kualitatif, teori dibatasi pada pengertian, suatu pernyataan sistematis yang berkaitan dengan seperangkat proposisi yang berasal dari data dan diuji kembali secara empiris (Moleong, 2005: 14).

Kajian terhadap konsep Kerajinan anyam merupakan salah satu dari kebudayaan yang dimiliki manusia sejak zaman prasejarah dalam rangka memenuhi kebutuhan akan sandang dan perlengkapan pendukung sehari-hari. Sampai saat ini, kerajinan anyam merupakan salah satu bentuk kerajinan yang terus dihasilkan oleh sebagian masyarakat Indonesia dengan ciri khas bentuk dan ornamen beragam dengan menggunakan bahan yang tersedia di alam, baik bambu, pandan, rotan, mending, dan ada juga yang membuatnya dengan menggunakan bahan kertas. Produk kerajinan anyam dalam kehidupan manusia, selain sebagai pemenuhan kebutuhan fungsional dalam arti fisik, tetapi kehadirannya juga dalam memenuhi kebutuhan estetik. Oleh karenanya jenis barang yang diproduksi menjadi sangat bervariasi, mulai dari perlengkapan kebutuhan rumah tangga yang bersifat tradisional sampai produk-produk aksesoris interior, maupun cendera mata (Syamsudin dalam jurnal Patria, 2015).

Anyaman adalah teknik membuat karya seni rupa yang dilakukan dengan cara menumpang tindihkan (menyilangkan) bahan anyam yang berupa lungsi dan pakan. Lungsi merupakan bahan anyaman yang menjadi dasar dari media anyam, sedangkan pakan yaitu bahan anyaman yang digunakan sebagai media anyaman dengan cara memasukkannya ke dalam bagian lungsi yang sudah siap untuk dianyam. Bahanbahan anyaman dapat dibuat dari tumbuh-tumbuhan yang sudah dikeringkan, seperti lidi, rotan, akar, dan dedaunan untuk dijadikan suatu rumpun yang kuat (tampar). Sedangkan alat yang digunakan untuk mengayam masih sangat sederhana seperti pisau pemotong, pisau penipis, dan catut bersungut bundar (Patria, 2015).

Berdasarkan bentuknya, anyaman dibagi menjadi dua, yaitu: 1) Anyaman dua dimensi, yaitu anyaman yang hanya memiliki ukuran panjang dan lebar saja, kalaupun seandainya memiliki ketebalan, ketebalan tersebut tidak terlalu diperhitungkan. 2) Anyaman tiga dimensi, yaitu anyaman yang memiliki ukuran panjang, lebar, dan tinggi (Dekrnas dalam jurnal Patria 2015).

\section{METODE PELAKSANAAN}

Pemecahan masalah dilakukan dengan menerapkan IPTEKS sesuai dengan permasalahan mitra dengan menggunakan metode pendekatan;

Rancangbangun media dan model pelatihan yang akan dijadikan sebagai panduan bahan latihan oleh Tim Pelaksana dan guru SDN 26 Parak Buruk dan SDN 53 Kampung Jambak sebagai peserta. (2) Penyuluhan yang dilakukan dengan metode ceramah dan tanya jawab dalam menyajikan materi untuk kedua aspek permasalahan. (3) Pelatihan atau workshop yang dilakukan oleh guru SDN 26 Parak Buruk dan SDN 53 


\section{Gorga Jurnal Seni Rupa \\ Volume 07 Nomor 02 \\ p-ISSN: 2301-5942 | e-ISSN: 2580-2380}

Kampung Jambak sebagai peserta pengabdian masyarakat, pelatihan dilakukan dengan bimbingan dari instruktur. (4) Penerapan merupakan praktik pembelajaran dengan materi sesuai dengan materi pengabdian kepada masyarakat ini yang dilakukan guru SDN 26 Parak Buruk dan SDN 53 Kampung Jambak dalam kelasnya sendiri.

\section{HASIL DAN PEMBAHASAN}

1. Persiapan Administrasi dan Rekrutmen Peserta Ada tiga jenis kegiatan yang dilaksanakan pada langkah persiapan ini, yaitu: (1) Penetapan jadwal konkrit dan tempat pelaksanaan kegiatan, (2) Koordinasi dan pengurusan izin, dan (3) Rekrutmen dan seleksi peserta.

Penetapan jadwal konkrit merupakan kegiatan penentuan/penetapan jadwal pelaksanaan kegiatan di lapangan. Tanggal 25 September 2018 telah dilakukan pertemuan dengan Kepala SDN 26 Parak Buruk dan tanggal 27 September 2018 dengan Kepala SDN 53 Kampung Jambak Padang. Hasil pertemuan tersebut adalah didapatkan kesepakatan antara Tim Pelaksana dengan Kepala SDN 26 Parak Buruk dan SDN 53 Kampung Jambak Padang. Kesepakatan tersebut adalah: Kegiatan dilaksanakan dari tanggal 6 sampai dengan 11 Oktober 2018, dan Tempat pelaksanaan kegiatan adalah di SDN 26 Parak Buruk Padang.

Koordinasi dan pengurusan izin dilakukan oleh Tim Pelaksana dengan Ketua LP2M UNP Padang. Hasil yang didapatkan adalah surat izin pelaksanaan kegiatan yang dikeluarkan LP2M UNP Padang dan ditujukan kepada: (1) Kepala UPTD Pendidikan Kecamatan Koto Tangah, (2) Kepala SDN 26 Parak Buruk, dan (3) SDN 53 Kampung Jambak Padang.

Rekrutmen dan seleksi peserta yang dilakukan atas kerjasama Tim Pelaksana dengan Kepala SDN 26 Parak Buruk dan SDN 53 Kampung Jambak Kecamatan Koto Tangah Padang. Hasilnya didapat dari hasil seleksi sebanyak 12 orang peserta dan ditambah dengan 2 orang kepala sekolah yang ikut dalam pelatihan tersebut. Hasil seleksi dilakukan oleh Kepala SDN 26 Parak Buruk dan SDN 53 Kampung Jambak Kecamatan Koto Tangah Padang.

2. Pelaksanakan Kegiatan, dengan jenis kegiatan dibagi atas: persiapan, pelaksanaan pelatihan/workshop, penerapan, dan evaluasi keberhasilan.

1). Persiapan pelatihan berupa: Rancang bangun media dan model pelatihan yang akan dijadikan sebagai pegangan bagi Tim Pelaksana dan peserta dalam mengikuti PKM ini. Hasil yang didapatkan adalah: (1) Media pembelajaran berupa power point, dan (2) Model prakarya dengan teknik anyaman.

Dihasilkan bahan dan alat praktikum yang akan digunakan selama kegiatan IbM ini dilaksanakan. Bahan dan alat tersebut dibagikan kepada peserta PKM.

2). Pelaksanaan pelatihan/workshop dengan jenis kegiatan berupa: Distribusi bahan dan alat kepada peserta PKM. Setiap peserta mendapatkan: bahan pelatihan berupa printout powerpoint, peralatan administrasi untuk keperluan pencatatan, bahan dan alat praktikum untuk mengaplikasikan pengetahuan yang dimiliki dalam bentuk karya.

Penyajian materi dalam bentuk penyuluhan untuk meningkatkan pemahaman peserta pelatihan terhadap materi PKM ini.

Setelah pembukaan, diberikan pretest tentang kemampuan awal peserta menguasai materi pemanfaatan bahan kertas sebagai bahan praktikum pada pembelajaran seni budaya dan prakarya. Selanjutnya dilaksanakan kegiatan, dan pada akhir pelaksanaan kegiatan kembali diukur kemampuan peserta.

Guru SDN 26 Parak Buruk dan SDN 53 Kampung Jambak belum dapat memahami pengertian, konsep, bahan, dan proses pembuatan karya seni rupa dan keterampilan dengan bahan kertas kado menggunakan teknik anyaman (sebagai bahan terbuang) sebagai bahan pembuatan karya praktikum. Dilihat dari hasil pengukuran kemampuan awal peserta, didapatkan sekitar $40 \%$ materi pengertian, konsep, bahan, dan proses pembuatan karya seni rupa dan keterampilan dengan bahan kertas kado menggunakan teknik anyaman sebagai bahan pembuatan karya praktikum yang dikuasai. Pada akhir kegiatan, dilakukan lagi pengukuran sekitar $80 \%$ materi pengertian, konsep, dan proses pembuatan karya seni rupa dan keterampilan dengan bahan kertas kado menggunakan teknik anyaman sebagai bahan pembuatan karya praktikum sudah dikuasai oleh Guru SDN Mitra. Tingkat persentese ini sudah melebihi target penguasaan yang ditetapkan sebanyak $75 \%$. Selanjutnya diberikan materi tentang: (1) Manajemen bahan praktikum keterampilan dari bahan kertas kado, dan (2) Konsep dan teknik mengolah kertas kado menjadi benda siap pakai. Bahan kertas kado ini diolah menjadi tiga jenis produk yaitu karya dua 


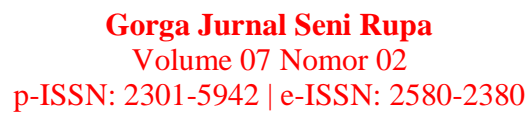

dimensi dan karya tiga dimensi (tempat pensil dengan 2 model) . Ketiga produk ini diolah dengan menggunakan teknik anyaman. Selama kegiatan penyajian materi, peserta terlihat antusias mengikuti kegiatan. Mencatat materi penting yang disajikan, aktif melakukan tanya jawab, tidak keluar ruangan kalau tidak terlalu penting.

Pelatihan/workshop untuk mengaplikasikan pengetahuan yang didapat, selama pelatihan dilakukan bimbingan oleh tim pelaksana. Pelatihan pada hari pertama Peserta membuat karya tiga dimensi menggunakan teknik anyaman dengan menambahkan kombinasi benang, bimbingan oleh tim pelaksana. Bahan yang dipergunakan di saat pelatihan adalah: bahan kertas kado bewarna yang digulung dengan menambahkan benang pada teknik anyamannya. Alat yang digunakan adalah gunting dan cutter, lem.

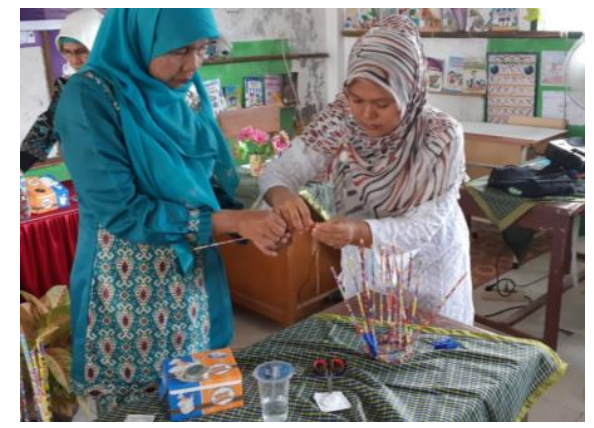

Gambar 1. Membimbing Guru dalam Menganyam

Pelatihan pada hari kedua peserta membuat karya tiga dimensi yang kedua yaitu: tempat pensil dengan bimbingan oleh tim pelaksana. Bahan yang dipergunakan di saat pelatihan adalah: kertas kado, alasnya diberi karton jerami. Alat yang digunakan adalah gunting, cutter, lem, penjepit jemuran.

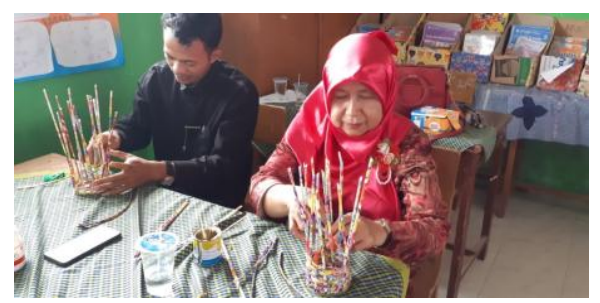

Gambar 2. Bapak dan Ibu Serius dalam Menganyam

Pelatihan pada hari ketiga peserta membuat karya dua dimensi yaitu: yang berfungsi untuk hiasan dinding dengan bimbingan oleh tim pelaksana. Bahan yang dipergunakan di saat pelatihan adalah: kertas kado, alasnya diberi karton jerami. Alat yang digunakan adalah gunting, cutter, lem.

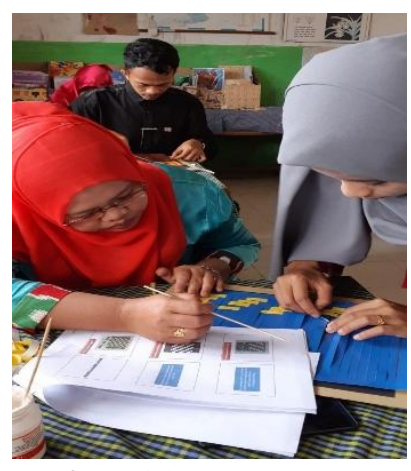

Gambar 3. Menjelaskan Cara Menganyam

Kegiatan pada tanggal 10-11 Oktober 2018 dilaksanakan pameran karya hasil pelatihan SDN 26 Parak Buruk dan SDN 53 Kampung Jambak Padang.

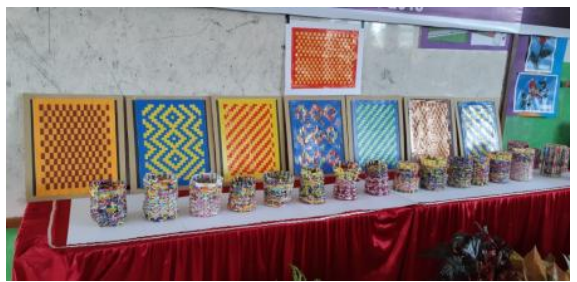

Gambar 4. Karya Bapak dan Ibu Guru

Target luaran kegiatan yang ditetapkan dalam kegiatan penerapan bahan dari kertas kado dengan menggunakan teknik anyaman sebagai bahan pembuatan karya keterampilan ini adalah peserta menghasilkan karya keterampilan dengan menggunakan bahan kertas kado sebagai bahan pembuatan karya keterampilan. Peserta mampu berkreasi dalam mengolah kertas kado menjadi benda siap pakai berupa karya dalam bentuk karya dua dimensi dan karya tiga dimensi. Artinya, setiap peserta dalam pelatihan tersebut memiliki keterampilan dan pengetahuan didalam mengolah kertas kado sebagai bahan terbuang. Pada akhir kegiatan peserta telah menghasilkan karya keterampilan dari bahan kertas kado dengan teknik anyaman. Dengan demikian maka target luaran yang ditetapkan sudah dapat dicapai dengan baik.

\section{KESIMPULAN DAN SARAN \\ 1.Kesimpulan}

1). Manajemen bahan praktikum pembelajaran seni rupa dan keterampilan.

Guru SDN Mitra telah dapat mengidentifikasi dan mengelola bahan kertas yang ada di lingkungan murid dapat dijadikan sebagai bahan praktikum pembelajaran Seni Rupa dan Prakarya. Sesuai dengan target luaran: (1) Telah dihasilkan produk media pelatihan dengan spesifikasi media pelatihan bahan 


\author{
Gorga Jurnal Seni Rupa \\ Volume 07 Nomor 02 \\ p-ISSN: 2301-5942 | e-ISSN: 2580-2380
}

praktikum dari bahan-bahan yang ada di lingkungan murid. Bahan tersebut diantaranya adalah (a) kertas kado yang bermotif. (b) kertas kado yang polos, (c) kertas kado yang dasarnya mengkilat, dan lain-lain. Selain dari bahan utama, ada bahan tambahan yang lain yang bisa dijadikan karya menggunakan teknik anyaman, antara lain: Art paper, kertas HVS, NCR paper, kertas buffalo-linen, fancy paper, kertas concorde, corugated paper, kertas ivory, samson paper, kertas duplex, kertas manila.

Dari berbagai jenis kertas tersebut, Guru SDN Mitra telah dapat memilih dan mempersiapkan bahan kertas kado yang ada di lingkungan murid sebagai bahan praktikum sesuai dengan tujuan pembelajaran yang akan dicapai. Pada kegiatan pelatihan, Guru SDN Mitra memilih bahan kertas kado yang bermotif, kertas kado yang polos untuk membuat karya dua dimensi dan karya tiga dimensi dengan menggunakan teknik anyaman. Pemilihan bahan praktikum dari bahan kertas kado ini telah membuka wawasan guru SDN Mitra, bahwa untuk pembelajaran Seni Budaya dan Prakarya tidak harus mengadakan bahan dengan cara membeli, tetapi berusaha menggali berbagai bahan kertas yang ada di lingkungan murid sebagai bahan praktikum pembuatan karya.

Telah dapat terjadi peningkatan pemahaman Guru SDN Mitra menguasai materi bahan praktikum dari bahan kertas kado yang ada di lingkungan murid. Pada awal kegiatan hanya sebanyak $40 \%$ materi bahan praktikum dari bahan-bahan terbuang berupa kertas yang ada di lingkungan murid dikuasai oleh Guru SDN Mitra. Pada akhir kegiatan sebanyak $78 \%$ materi bahan praktikum dari bahan-bahan terbuang berupa bahan kertas yang ada di lingkungan murid sudah dikuasai oleh Guru SDN Mitra. Tingkat persentese ini sudah melebihi target penguasaan yang ditetapkan sebanyak $75 \%$.

2). Penguasaan dan penerapan materi pembelajaran seni rupa dan prakarya dengan target luaran berupa:

Peningkatan pemahaman oleh Guru SDN Mitra dengan spesifikasi minimal $75 \%$ materi pelatihan dikuasai oleh Guru SDN Mitra. Target luaran kegiatan ini sudah dapat dicapai. Hasil pengukuran kemampuan awal, hanya sebanyak $40 \%$ materi pengertian, konsep, bahan, dan proses pembuatan karya seni rupa dan keterampilan dengan mempergunakan bahan terbuang berupa bahan kertas kado yang diolah dengan menggunakan teknik anyaman sebagai bahan pembuatan karya praktikum yang dikuasai oleh Guru SDN Mitra. Rendahnya kemampuan peserta pelatihan ini disebabkan mereka baru mengenal cara mengolah atau mengkreasikan kertas kado menjadi sebuah karya yang bernilai seni dengan menggunakan teknik anyaman ini. Selama ini guru SDN Mitra belum bisa mengkreasikan atau mengolah kertas kado menjadi karya yang bernilai seni yang dijadikan sebagai bahan praktikum pada pembelajaran seni budaya dan prakarya. Pada akhir kegiatan, sebanyak $78 \%$ materi pengertian, konsep, bahan, dan proses pembuatan karya seni rupa dan prakarya dengan mempergunakan bahan terbuang berupa kertas kado dengan menggunakan teknik anyaman sebagai bahan pembuatan karya praktikum sudah dikuasai oleh Guru SDN Mitra. Tingkat persentese ini sudah melebihi target penguasaan yang ditetapkan sebanyak $75 \%$.

Produk berupa model karya keterampilan dari bahanbahan terbuang berupa kertas kado dengan spesifikasi dihasilkan tiga model karya keterampilan dari bahanbahan kertas kado dengan teknik anyaman. Hasil yang didapatkan adalah dihasilkan tiga model karya keterampilan dari bahan kertas kado. Dengan demikian sudah sesuai dengan target luaran yang ditetapkan. Model produk ini dijadikan sebagai media pembelajaran/pelatihan untuk memperlancar interaksi komunikasi selama kegiatan penyampaian informasi pelatihan.

Minimal peserta menghasilkan tiga karya keterampilan dari bahan-bahan terbuang berupa kertas kado yang ada di sekeliling murid dengan proses pengerjaannya menggunakan teknik anyaman. Peserta telah menghasilkan karya keterampilan dari bahan terbuang berupa kertas kado sesuai dengan target luaran yang ditetapkan, yaitu peserta telah menghasilkan tiga karya keterampilan dari bahanbahan terbuang berupa kertas kado yang ada di sekeliling murid, karya tersebut adalah berupa satu karya dua dimensi, dua buah karya yang bersifat tiga dimensi dengan mempergunakan bahan terbuang berupa kertas kado. Karya-karya yang dibuat oleh peserta tersebut telah dipamerkan dari tanggal 10 sampai dengan 11 Oktober 2018 di salah satu ruangan kelas SDN 26 Parak Buruk Padang.

\section{Saran}

Berdasarkan hasil kegiatan, maka disarankan: (1) Kegiatan ini dapat diterapkan guru dalam kegiatan pembelajaran di dalam kelas. (2) Perlu dilakukan berbagai jenis pelatihan lain kepada Guru SD Mitra, terutama menyangkut materi pembelajaran, dan materi proses pembelajaran. 


\section{DAFTAR RUJUKAN}

Departemen Pendidikan Nasional, 2003. UndangUndang Nomor 20 Tahun 2003. Tentang Sistem Pendidikan Nasional, Jakarta: Depdiknas.

Depdiknas. 2006a. Pelayanan Profesional Kurikulum 2006. Jakarta: Departemen Pendidikan Nasional.

Depdiknas. 2003b. Standar Kompetensi Mata Pelajaran Kerajinan Tangan dan Kesenian. Jakarta: Departemen Pendidikan Nasional. 